\title{
Detection of an elevated HER2 expression in MCF-7 breast cancer cells overexpressing estrogen receptor $B 1$
}

\author{
CLAUS LATTRICH, INGOLF JUHASZ-BOESS, OLAF ORTMANN and OLIVER TREECK
}

Department of Obstetrics and Gynecology, University of Regensburg, D-93053 Regensburg, Germany

Received September 6, 2007; Accepted November 16, 2007

\begin{abstract}
The estrogen receptor (ER) expression and HER2 amplification are important factors in determining the prognosis and therapy of breast cancer. Interactions between the two signaling pathways for example resulted in ER $\alpha$ dependent regulation of HER2 expression in breast cancer cells. In this study, we investigated to what extent ERß is able to affect the HER2 expression. For this purpose, we analyzed HER2 levels in ERß1-overexpressing clones of the breast cancer cell lines MCF-7 and SK-BR-3 and of the ovarian cancer cell lines SK-OV-3 and OVCAR-3 by both RT-PCR and Western blot analysis. Treatment with ligand 17- $\beta$ estradiol diminished the HER2 expression in MCF-7 wild-type cells, an effect partially inhibited by treatment with $4-\mathrm{OH}$ tamoxifen. MCF-7 breast cancer cells stably overexpressing ERß1 exhibited elevated $>5$-fold HER2 mRNA levels and elevated $>3$-fold HER2 protein levels even in the absence of estradiol. In contrast, ERß1 overexpression did not affect HER2 protein levels in the ER $\alpha$-positive OVCAR-3 ovarian cancer cells and in the HER2 overexpressing, hormoneindependent SK-BR-3 and SK-OV-3 cells. By demonstrating the elevated HER2 expression in a hormone-dependent breast cancer cell line overexpressing ERß1, our data suggest the presence of cross-talk between the two receptors. This is one of the molecular mechanisms underlying the significant ERß/HER2 co-expression observed in recent clinical studies.
\end{abstract}

\section{Introduction}

The growth of hormone-dependent breast and ovarian cancer cells can be regulated by estrogen receptors (ER) and receptor tyrosine kinases such as HER2. Estrogen receptors ER $\alpha$ and $-\beta$ are expressed in normal breast and ovary cancer cells and in malignancies derived from these tissues (1-3). Although the

Correspondence to: Dr Oliver Treeck, Klinik für Frauenheilkunde und Geburtshilfe, Universität Regensburg, Caritas Krankenhaus St. Josef, Landshuter Str. 65, D-93053 Regensburg, Germany

E-mail: otreeck@caritasstjosef.de

Key words: breast cancer, ovarian cancer, estrogen receptor $\beta$, HER2 role of ERß in breast and ovary is not fully elucidated, the interaction of $E R \alpha$ and $-\beta$ is important for the normal development and function of these tissues. In animal studies, while ER $\alpha$ has been shown to be essential for normal mammary gland development, ERß effects are more subtle, with roles in terminal differentiation (4). ERß is the dominant estrogen receptor in normal breast tissues (5-7), but its expression declines during tumorigenesis $(8,9)$ suggesting a role for ERß as a tumor suppressor in breast tissues (10). However, $\sim 55-72 \%$ of primary breast cancer cases show a lower or higher expression of ERß (11-14). Our recent studies and others suggest that ERß has similar functions in ovarian carcinogenesis $(15,16)$. Malignant ovarian tumors originating from the epithelial surface constitute $~ 90 \%$ of ovarian cancers and express low levels of ERß, compared to normal tissues. In addition, the restoration of ERß in ovarian cancer cells, leads to a strong inhibition of their proliferation and motility, while apoptosis is enhanced (15).

The receptor tyrosine kinase HER2 is overexpressed in breast and ovarian cancer tissues. In $20 \%$ of all ovarian epithelial cancer, HER2 is overexpressed (17-19) and may be associated with chemoresistance $(20,21)$. The amplification or overexpression of the HER2 gene is found in $20-25 \%$ of human breast cancers (22) and is known as a poor prognostic marker and therapeutic target $(23,24)$.

Recent studies demonstrated an interaction between the ER $\alpha$ and HER2 signal transduction $(25,26)$. For example estradiol is able to reduce HER2 expression in an ER $\alpha$ dependent manner (27). This may be a reason why the coexpression of the two receptors, which is correlated with a poor prognosis, is infrequent (28-30). In contrast, a significant positive correlation between HER2 overexpression and ERß expression was reported $(11,13)$.

In this study, we elucidated the molecular mechanism underlying this co-expression of ERß and HER2. For this purpose, we examined the effect of the ERß overexpression on HER 2 expression in breast and ovarian cancer cell lines.

\section{Materials and methods}

Materials. DMEM/F12 culture medium was obtained from Invitrogen (Karlsruhe, Germany), fetal calf serum (FCS) was purchased from PAA (Pasching, Austria) and 17- $ß$ estradiol, 4-OH tamoxifen and serum replacement 2 (SR2) were obtained from Sigma (Deisenhofen, Germany). M-MLV-P 
Table I. Primer sequences used for RT-PCR amplification.

\begin{tabular}{lll}
\hline Target & Oligonucleotides & Sequences 5'-3' \\
\hline ER $\alpha$ & ER $\alpha 1$ & TGATGAAAGGTGGGATACGA \\
& ER $\alpha 2$ & AAGGTTGGCAGCTCTCATGT \\
ERß1 & ERß1 & CAAGGCCGGTGTGTTTATCT \\
& ERß2 & GGCGTCACTGAGACTGTGG \\
HER2 & HER2-1 & AACTGCACCCACTCCTGTGT \\
& HER2-2 & TGATGAGGATCCCAAAGACC \\
3-actin & actin-2573 & CTGTGGCATCCACGAAACTA \\
& actin-2876 & CGCTCAGGAGGAGCAATG \\
\hline
\end{tabular}

reverse transcriptase was purchased from Promega (Mannheim, Germany). The RNeasy mini kit, RNase-free DNase set and Quantitect SYBR-Green PCR kit were obtained from Qiagen (Hilden, Germany). PCR primers were synthesized at Metabion (Planegg-Martinsried, Germany). Platinum Pfx polymerase was purchased at Invitrogen (Karlsruhe).

Cell culture. MCF-7, SK-BR-3, OVCAR-3 and SK-OV-3 breast and ovarian cancer cells were obtained from the American Type Culture Collection (Manassas, USA). Cells were maintained in phenol red-free DMEM/F12 medium supplemented with $10 \%$ FCS. Cells were cultured with 5\% $\mathrm{CO}_{2}$ at $37^{\circ} \mathrm{C}$ in a humidified incubator. Before treatment with E2 or 4-OH tamoxifen, FCS was replaced by $1 \mathrm{x}$ serum replacement 2 (SR2). Stimulation was carried out the following day using $3 \mathrm{nM}$ E2 alone or in combination with $100 \mathrm{nM} 4-\mathrm{OH}$ tamoxifen for $48 \mathrm{~h}$ prior to RNA and protein extraction.

Reverse transcription and PCR. Total RNA was isolated by means of the RNeasy kit (Qiagen) according to the manufacturer's instructions. From $1 \mu \mathrm{g}$ total RNA, cDNA was synthesized using $100 \mathrm{U}$ M-MLV-P reverse transcriptase (Promega), $2.5 \mathrm{mM}$ dNTP mixture and $50 \mathrm{pM}$ random primers (Invitrogen). For real-time PCR detection of ER $\alpha$, ERB1 or HER2 (primer sequences in Table I), $2 \mu 1$ cDNA was amplified using the Quantitect SYBR-Green PCR kit (Qiagen) and the LightCyler PCR device (Roche Diagnostics, Mannheim, Germany). The PCR program was $95^{\circ} \mathrm{C}$ for 15 min, followed by $35 \mathrm{PCR}$ cycles $\left(95^{\circ} \mathrm{C}\right.$ for $10 \mathrm{sec}, 56^{\circ} \mathrm{C}$ for $30 \mathrm{sec}$ and $72^{\circ} \mathrm{C}$ for $30 \mathrm{sec}$ ) and a final extension for $5 \mathrm{~min}$ at $72^{\circ} \mathrm{C}$, followed by a standard melting curve analysis. In all the RT-PCR experiments, a 190 bp ß-actin fragment was amplified as a reference gene using intron-spanning primers actin-2573 and -2876. After performing dilution experiments with a sample cDNA over a 100 -fold range confirming the PCR efficiencies of all primer pairs to be approximately equal (31), data were analyzed using the comparative $\Delta \Delta \mathrm{C}_{\mathrm{T}}$ method (32) by calculating the difference between the threshold cycle $\left(\mathrm{C}_{\mathrm{T}}\right)$ values of the target and reference gene of each sample and then comparing the resulting $\Delta \mathrm{C}_{\mathrm{T}}$ values between different samples. In these experiments, mRNA not subjected to reverse transcription was used as a negative control to distinguish cDNA and vector or genomic DNA amplification.
Antibodies and Western blot analysis. Cells were lysed in RIPA buffer $1 \%(\mathrm{v} / \mathrm{v})$ Igepal CA-630, 0.5\% (w/v) sodium deoxycholate, $0.1 \%(\mathrm{w} / \mathrm{v})$ sodium dodecyl sulphate (SDS) in phosphate-buffered solution (PBS) containing aprotinin and sodium orthovanadate. Aliquots containing $15 \mu \mathrm{g}$ protein were resolved by $10 \%(w / v)$ SDS-polyacrylamide gel electrophoresis, followed by electrotransfer to a PVDF hybond (Amersham, UK) membrane. Immunodetection was carried out using the HER2 antibody NEU (C-18) (Santa Cruz Biotechnology, Santa Cruz, USA) or B-actin antibody (8226, ABCAM, Germany) diluted at 1:5000 in PBS containing 5\% skim milk (w/v) followed by horseradish peroxidase conjugated secondary antibody (diluted at 1:50000), which was detected using the chemiluminescence (ECL) system (Amersham, Buckinghamshire, UK).

\section{Results}

Expression of ER $\alpha, E R \beta$ and HER2 in breast and ovarian cancer cell lines. To characterize the employed cancer cell lines, we first examined the expression of HER2, ER $\alpha$ and ERß in the cells on the mRNA level. The real-time RT-PCR analysis revealed a strong expression of HER2 in the SK-BR-3 breast and SK-OV-3 ovarian cancer cells, which are known to be HER2-overexpressing and estrogen-unresponsive. In contrast, the estrogen-responsive MCF-7 breast and OVCAR-3 ovarian cancer cells exhibited only relatively low HER2 mRNA levels (Fig. 1). All four cell lines tested expressed detectable levels of ERß1 mRNA, which were highest in the ER $\alpha$-positive, estrogen-responsive MCF-7 and OVCAR-3 cells (Fig. 2). As expected ERß1 mRNA levels were shown to be strongly elevated in the ERß1-overexpressing $\left(\mathrm{ER} \beta^{+}\right)$ clones of these cell lines as previously described $(15,33)$. The levels were generated by stable transfection with an ERß1 expression plasmid (Fig. 2). Real-time RT-PCR analysis of the $\mathrm{ER} \alpha$ expression confirmed the previously described positive ER $\alpha$ status of MCF-7 and OVCAR-3 cells and the absence of functional ER $\alpha$ in the SK-BR-3 and SK-OV-3 cells (data not shown).

Effect of ERß overexpression on HER2 expression in breast and ovarian cancer cell lines. We analyzed the expression of the HER2 gene in the ERß1-overexpressing breast and 


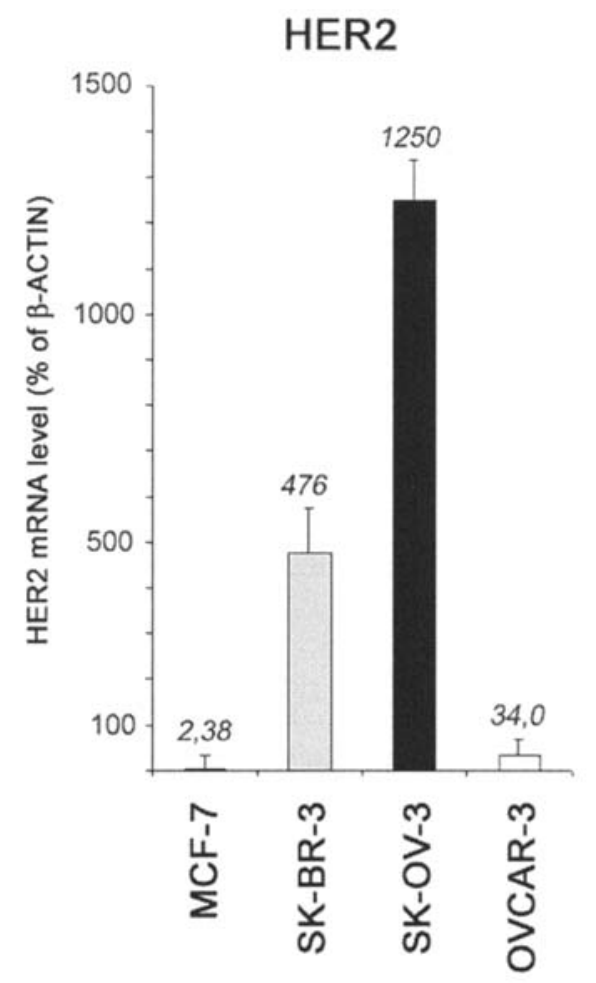

Figure 1. HER2 mRNA levels in breast and ovarian cancer cell lines. Total RNA isolated from the indicated cancer cell lines was subjected to real-time RT-PCR. Relative HER2 mRNA levels are expressed in percent of $\beta$-actin control $(n=4)$.

ovarian cancer cell lines on the mRNA and protein levels. HER 2 mRNA levels were elevated $>5$-fold in the MCF-7/ER ${ }^{+}$ cells (Fig. 3a) and elevated $\sim 4$-fold in the SK-OV-3/ERß ${ }^{+}$ cells (Fig. 4a) cultured in serum- and steroid hormone-free medium when compared to wild-type cells. The addition of 17- $\beta$ estradiol (E2) significantly decreased the HER2 mRNA levels in the hormone-dependent, ER $\alpha$-positive breast cancer cell line MCF-7 down to $59.7 \%$ (Fig. 3a), but not in the hormone-independent ovarian cancer cell line SK-OV-3. This effect could be partially inhibited in the MCF-7 cells by treatment with 4-OH tamoxifen and was also present in the $\mathrm{MCF}-7 / \mathrm{ER} \beta^{+}$cells. In contrast, the HER 2 mRNA levels were not altered in the SK-BR-3/ERß ${ }^{+}$breast cancer and OVCAR3/ER $\beta^{+}$ovarian cancer cells.

The HER2 protein levels as assessed by Western blot analysis were elevated $>3$-fold in the MCF-7 cells overexpressing ERß1 (Fig. $3 b$ and c). This effect was not dependent on the presence of E2 and was not affected by the addition of 4-OH tamoxifen. In contrast, in the SK-OV-3/ $E R \beta^{+}$cells exhibiting increased amounts of HER 2 transcripts, we detected only a marginal increase of the HER2 protein level which was not significant (Fig. $4 \mathrm{~b}$ and c). SK-BR-3 and OVCAR-3 cells overexpressing ERß1 did not exhibit changes in the HER2 expression on the protein level.

\section{Discussion}

In this report we demonstrated that elevated ERß receptor levels can trigger a significant increase of HER2 expression in hormone-dependent breast cancer cells. Our findings are

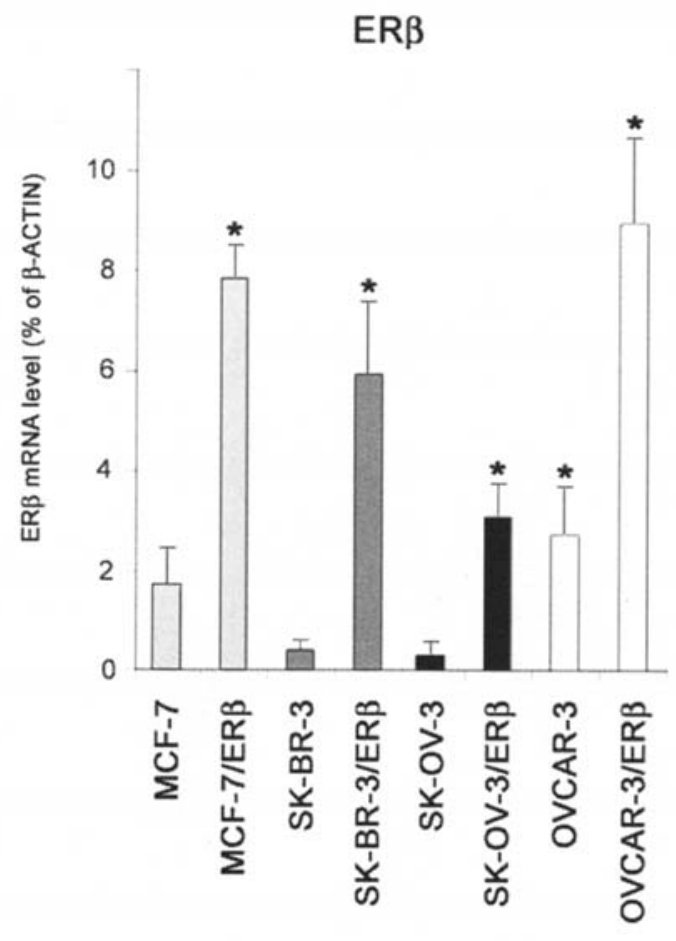

Figure 2. Estrogen receptor $\beta$ mRNA levels in wild-type and stably transfected $\mathrm{ER}^{+}{ }^{+}$cell lines. Total RNA isolated from the indicated cancer cell lines and clones was subjected to real-time RT-PCR. Relative ERß mRNA levels are expressed in percent of $\beta$-actin control $(n=4) ;{ }^{*} \mathrm{p}<0.01$ vs. wild-type.

one explanation for the recently published observation that ERß and HER2 expression is strongly and positively correlated in primary breast cancer $(11,13)$.

The interactions between the ER $\alpha$-mediated cellular estrogen response and HER2 signal transduction have previously been reported. The activity of ER $\alpha$ and estrogenrelated receptor $\alpha 1$ is modulated by the HER 2 signaling pathway $(25,26)$. On the other hand, the HER2 expression is known to be suppressed by ER $\alpha$-dependent signaling mechanisms (27). We also examined whether cross-talk exists between ERß and HER2 in breast and ovarian cancer cells.

For this purpose, we used a set of four hormone-dependent and -independent breast and ovarian cancer cell lines exhibiting different levels of ER $\alpha$ including the HER2overexpressing cell lines SK-BR-3 and SK-OV-3. We compared the HER2 expression level of these wild-type cells to the expression of this receptor tyrosine kinase in ERß1overexpressing clones of these cell lines generated by stable transfection with an ERß1-expression plasmid as previously described $(15,33)$. The ERß1-overexpressing clones used in this study exhibited elevated ERß mRNA levels which are still in a physiological range resembling the ERß expression level of tumor cell lines such as MDA-MD-231 (34) and are characterized by a significantly slowed proliferation, increased basal apoptosis and impaired motility $(15,33)$. These characteristics of our $\mathrm{ER}^{+}$clones are in line with reports from other groups demonstrating that ERß may negatively regulate cellular proliferation, promote apoptosis and thus may have a protective role in hormone-dependent tissues such as breast and prostate (35-37). Similar observations 
a)

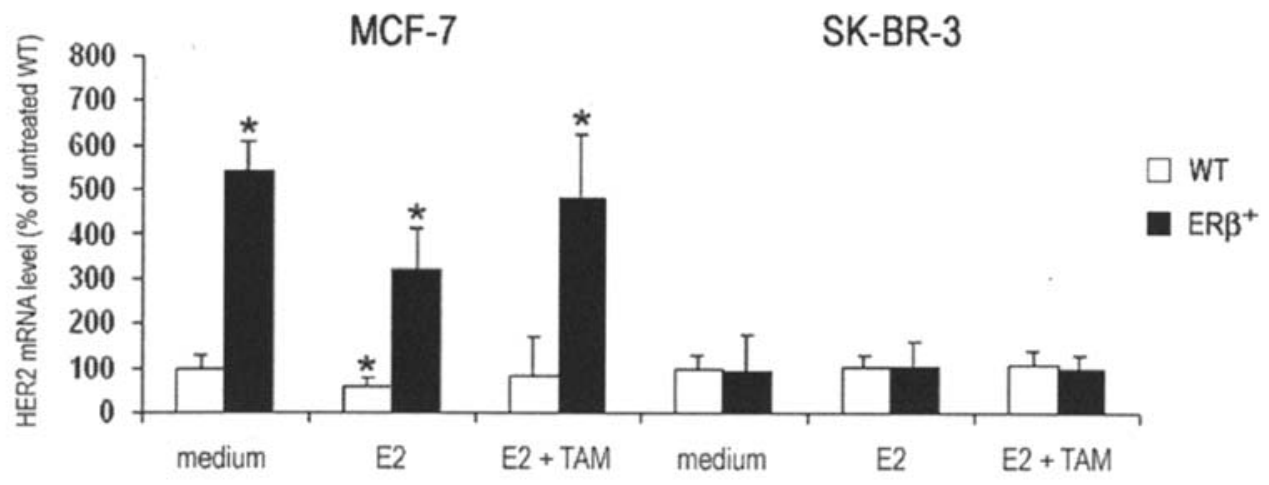

b)

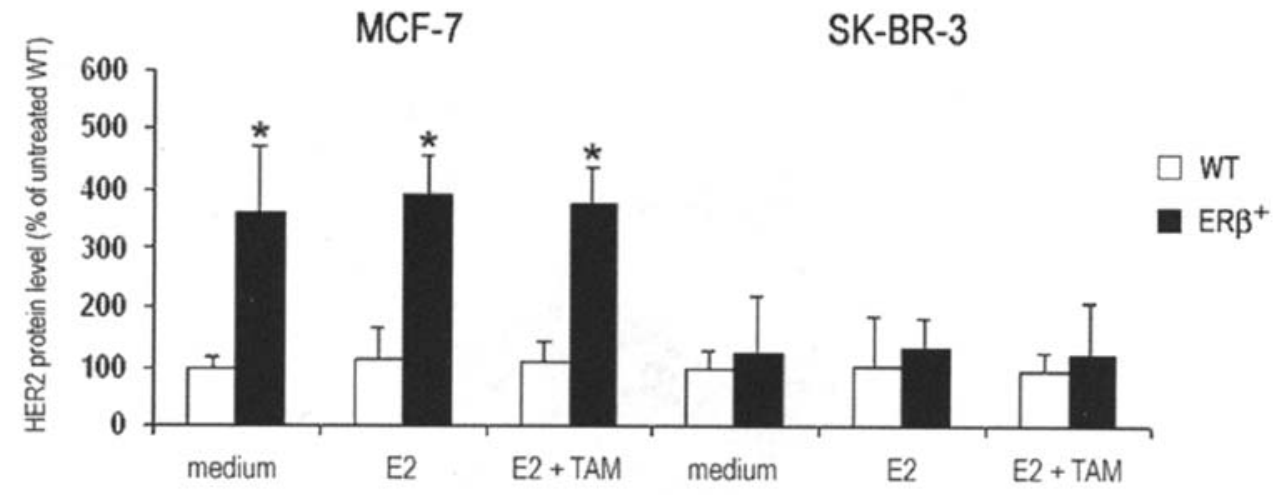

c)

MCF-7

SK-BR-3

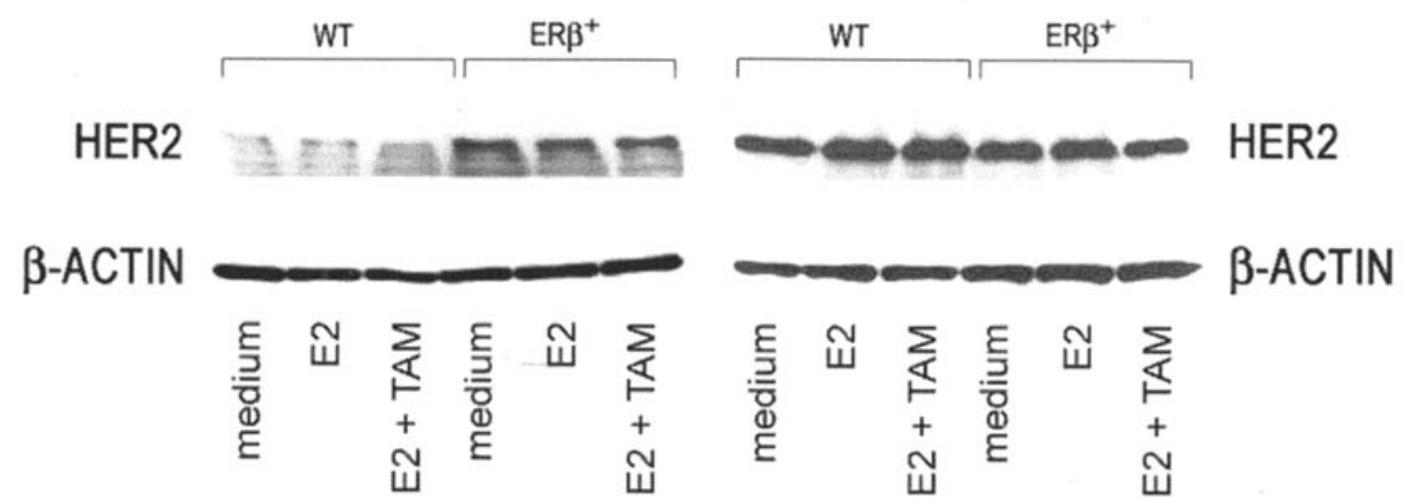

Figure 3. HER2 expression in wild-type and ERß-transfected breast cancer cell lines. The indicated cell lines and clones were cultured in steroid-hormone-

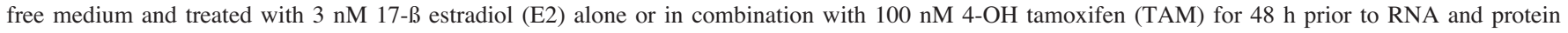
preparation. (a) HER2 mRNA levels expressed in percent of the $\beta$-actin control. (b) HER2 Protein level in percent of the untreated wild-type control. (c) Representative Western blot ( $\mathrm{n}=4) ;{ }^{*} \mathrm{p}<0.01$ vs. wild-type.

were made in studies analyzing the function of ERß in ovarian cancer cells (15). These observations taken together with the fact that the ERß expression is reported to decrease during tumorigenesis suggest that ERß has a tumor-suppressor function in hormone-dependent tissues. In contrast, the HER-2 overexpression and/or amplification in breast cancer with positive hormone receptor status is correlated with an aggressive tumor phenotype (38). Thus, our findings, which 
a)

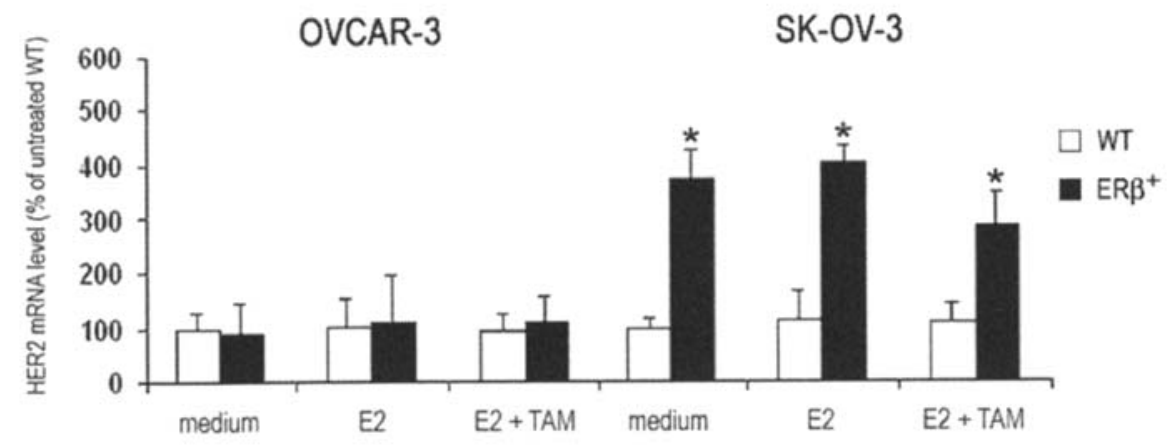

b)

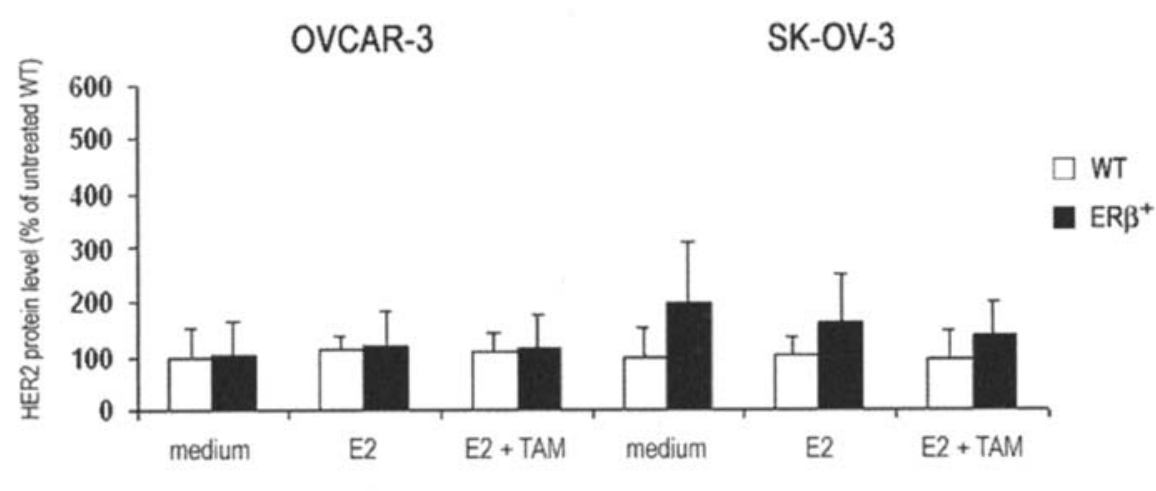

c)

OVCAR-3

SK-OV-3

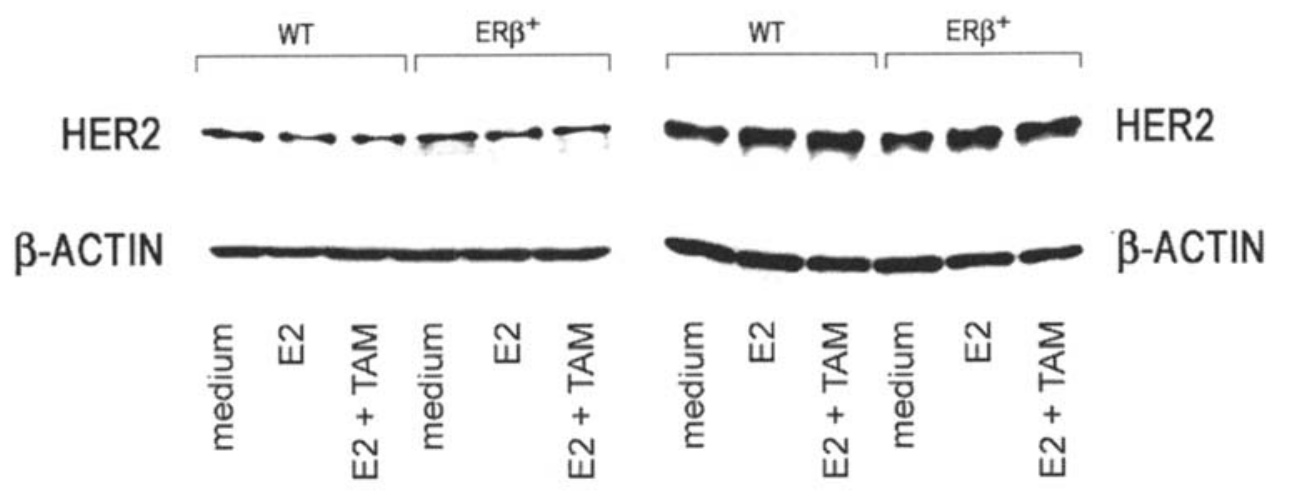

Figure 4. HER2 expression in wild-type and ERß-transfected ovarian cancer cell lines. The indicated cell lines and clones were cultured in steroid-hormonefree medium and treated with $3 \mathrm{nM} 17-\beta$ estradiol (E2) alone or in combination with $100 \mathrm{nM} 4-\mathrm{OH}$ tamoxifen (TAM) for $48 \mathrm{~h}$ prior to RNA and protein preparation. (a) HER2 mRNA levels expressed in percent of the $\beta$-actin control. (b) HER2 Protein level in percent of the untreated wild-type control. (c) Representative Western blot $(n=4) ;{ }^{*}<<0.01$ vs. wild-type.

demonstrate that an overexpression of ER $\beta$ leads to the elevation of HER2 expression in ER $\alpha$-positive MCF-7 breast cancer cells, are noteworthy. However, results from our previous studies demonstrating a diminished proliferation of the MCF-7/ERß+ clone when compared to wild-type MCF-7 cells clearly suggest that the up-regulation of HER2 is not sufficient to trigger increased cell growth.
We confirmed the results of previous studies by showing that treatment with E2 is able to diminish the HER2 expression in MCF-7 wild-type cells expressing ER $\alpha$ (27). Given that the overexpression of ERß1 was able to increase the HER2 expression in this cell line, it is tempting to speculate that the ER $\alpha$-triggered down-regulation of HER2 was counteracted by a high expression of ERß1 in a ligand-independent 
manner. This interpretation of our observations would be in line with previous reports demonstrating that ER $\beta$ acts as an ER $\alpha$ antagonist in specific settings $(39,40)$.

The fact that we did not observe any significant effect of ERB1 overexpression on HER2 protein levels of SK-OV-3 and SK-BR-3 cells could simply be explained by the strong HER2 overexpression already present in the two cell lines which did not allow for the detection of possible ERß actions $(41,42)$. The second reason for the observed unchanged HER2 expression in these cell lines was the known loss of functional ER $\alpha$ in SK-OV-3 and SK-BR-3 cells which does not allow for the observation of antagonistic ERß effects $(39,40)$.

In this study, we reported the up-regulation of the HER2 receptor tyrosine kinase expression in estrogen-responsive MCF-7 breast cancer cells overexpressing ERß1. This effect could be one of the reasons for the significantly correlated co-expression of the two receptors observed in recent clinical reports.

\section{Acknowledgements}

We thank Angelika Vollmer and Tanja Späth for their expert technical assistance.

\section{References}

1. Kuiper GG, Enmark E, Pelto-Huikko M, Nilsson S and Gustafsson JA: Cloning of a novel receptor expressed in rat prostate and ovary. Proc Natl Acad Sci USA 93: 5925-5930, 1996.

2. Enmark E, Pelto-Huikko M, Grandien K, et al: Human estrogen receptor beta-gene structure, chromosomal localization, and expression pattern. J Clin Endocrinol Metab 82: 4258-4265, 1997.

3. Speirs V, Carder PJ, Lane S, Dodwell D, Lansdown MR and Hanby AM: Oestrogen receptor beta: what it means for patients with breast cancer. Lancet Oncol 5: 174-181, 2004.

4. Forster C, Makela S, Warri A, et al: Involvement of estrogen receptor beta in terminal differentiation of mammary gland epithelium. Proc Natl Acad Sci USA 99: 15578-15583, 2002.

5. Shaw JA, Udokang K, Mosquera JM, Chauhan H, Jones JL and Walker RA: Oestrogen receptors alpha and beta differ in normal human breast and breast carcinomas. J Pathol 198: 450-457, 2002.

6. Speirs V, Adams IP, Walton DS and Atkin SL: Identification of wild-type and exon 5 deletion variants of estrogen receptor beta in normal human mammary gland. J Clin Endocrinol Metab 85: 1601-1605, 2000.

7. Speirs V, Skliris GP, Burdall SE and Carder PJ: Distinct expression patterns of ER alpha and ER beta in normal human mammary gland. J Clin Pathol 55: 371-374, 2002.

8. Leygue E, Dotzlaw H, Watson PH and Murphy LC: Altered estrogen receptor alpha and beta messenger RNA expression during human breast tumorigenesis. Cancer Res 58: 3197-3201, 1998 .

9. Roger P, Sahla ME, Makela S, Gustafsson JA, Baldet P and Rochefort H: Decreased expression of estrogen receptor beta protein in proliferative preinvasive mammary tumors. Cancer Res 61: 2537-2541, 2001.

10. Skliris GP, Munot K, Bell SM, et al: Reduced expression of oestrogen receptor beta in invasive breast cancer and its reexpression using DNA methyl transferase inhibitors in a cell line model. J Pathol 201: 213-220, 2003.

11. Umekita Y, Souda M, Ohi Y, et al: Expression of wild-type estrogen receptor beta protein in human breast cancer: specific correlation with HER2/neu overexpression. Pathol Int 56: 423-427, 2006

12. Jarvinen TAH, Pelto-Huikko M, Holli $\mathrm{K}$ and Isola J: Estrogen receptor $\mathrm{b}$ is coexpressed with ER a and PR and associated with nodal status, grade, and proliferation rate in breast cancer. Am J Pathol 156: 29-35, 2000.
13. Choi Y and Pinto M: Estrogen receptor beta in breast cancer: associations between ER beta, hormonal receptors, and other prognostic biomarkers. Appl Immunohistochem Mol Morphol 13: 19-24, 2005

14. Nakopoulou L, Lazaris AC, Panayotopoulou EG, et al: The favourable prognostic value of oestrogen receptor $b$ immunohistochemical expression in breast cancer. J Clin Pathol 57: 523-528, 2004.

15. Treeck O, Pfeiler G, Mitter D, Lattrich C, Piendl G and Ortmann O: Estrogen receptor \{beta\} 1 exerts antitumoral effects on SK-OV-3 ovarian cancer cells. J Endocrinol 193: 421-433, 2007.

16. Lazennec G: Estrogen receptor beta, a possible tumor suppressor involved in ovarian carcinogenesis. Cancer Lett 231: 151-157, 2006.

17. Afify AM, Werness BA and Mark HF: HER-2/neu oncogene amplification in stage I and stage III ovarian papillary serous carcinoma. Exp Mol Pathol 66: 163-169, 1999.

18. Seki A, Yoshinouchi M, Seki N, Kodama J, Miyagi Y and Kudo T: Detection of c-erbB-2 and FGF-3 (INT-2) gene amplification in epithelial ovarian cancer. Int J Oncol 17: 103-106, 2000.

19. Kim YT, Kim JW and Lee JW: c-erbB-2 oncoprotein assay in ovarian carcinoma and its clinical correlation with prognostic factors. Cancer Lett 132: 91-97, 1998.

20. Sasaki N, Kudoh K, Kita T, Tsuda H, Furuya K and Kikuchi Y: Effect of HER-2/neu overexpression on chemoresistance and prognosis in ovarian carcinoma. J Obstet Gynaecol Res 33: 17-23, 2007.

21. Malamou-Mitsi V, Crikoni O, Timotheadou E, et al: Prognostic significance of HER-2, p53 and Bcl-2 in patients with epithelial ovarian cancer. Anticancer Res 27: 1157-1165, 2007.

22. Slamon DJ, Godolphin W, Jones LA, et al: Studies of the HER$2 /$ neu proto-oncogene in human breast and ovarian cancer. Science 244: 707-712, 1989 .

23. Goldhirsch A, Glick JH, Gelber RD, Coates AS, Thurlimann B and Senn HJ: Meeting highlights: international expert consensus on the primary therapy of early breast cancer 2005. Ann Oncol 16: $1569-1583,2005$.

24. Jukkola A, Bloigu R, Soini Y, Savolainen ER, Holli K and Blanco G: c-erbB-2 positivity is a factor for poor prognosis in breast cancer and poor response to hormonal or chemotherapy treatment in advanced disease. Eur J Cancer 37: 347-354, 2001.

25. Ariazi EA, Kraus RJ, Farrell ML, Jordan VC and Mertz JE: Estrogen-related receptor alpha1 transcriptional activities are regulated in part via the ErbB2/HER2 signaling pathway. Mol Cancer Res 5: 71-85, 2007.

26. Stoica GE, Franke TF, Moroni M, et al: Effect of estradiol on estrogen receptor-alpha gene expression and activity can be modulated by the ErbB2/PI 3-K/Akt pathway. Oncogene 22: 7998-8011,2003.

27. Read LD, Keith D Jr, Slamon DJ and Katzenellenbogen BS: Hormonal modulation of HER-2/neu protooncogene messenger ribonucleic acid and p185 protein expression in human breast cancer cell lines. Cancer Res 50: 3947-3951, 1990.

28. Ciocca DR, Gago FE, Fanelli MA and Calderwood SK: Coexpression of steroid receptors (estrogen receptor alpha and/or progesterone receptors) and Her-2/neu: Clinical implications. J Steroid Biochem Mol Biol 102: 32-40, 2006.

29. Dowsett M: Overexpression of HER-2 as a resistance mechanism to hormonal therapy for breast cancer. Endocr Relat Cancer 8: 191-195, 2001.

30. Zeillinger R, Kury F, Czerwenka K, et al: HER-2 amplification, steroid receptors and epidermal growth factor receptor in primary breast cancer. Oncogene 4: 109-114, 1989.

31. Stahlberg A, Aman P, Ridell B, Mostad P and Kubista M: Quantitative real-time PCR method for detection of Blymphocyte monoclonality by comparison of kappa and lambda immunoglobulin light chain expression. Clin Chem 49: 51-59, 2003.

32. Livak KJ and Schmittgen TD: Analysis of relative gene expression data using real-time quantitative PCR and the 2 (-Delta Delta C(T)) method. Methods 25: 402-408, 2001.

33. Treeck O, Pfeiler G, Horn F, et al: Novel estrogen receptor beta transcript variants identified in human breast cancer cells affect cell growth and apoptosis of COS-1 cells. Mol Cell Endocrinol 264: 50-60, 2007

34. Poola I, Abraham $\mathrm{J}$ and Baldwin K: Identification of ten exon deleted ER[beta] mRNAs in human ovary, breast, uterus and bone tissues: alternate splicing pattern of estrogen receptor [beta] mRNA is distinct from that of estrogen receptor [alpha]. FEBS Lett 516: 133-138, 2002. 
35. Lazennec G, Bresson D, Lucas A, Chauveau C and Vignon F: ER beta inhibits proliferation and invasion of breast cancer cells. Endocrinology 142: 4120-4130, 2001.

36. Cheng J, Lee EJ, Madison LD and Lazennec G: Expression of estrogen receptor beta in prostate carcinoma cells inhibits invasion and proliferation and triggers apoptosis. FEBS Lett 566: 169-172, 2004.

37. Guerini V, Sau D, Scaccianoce E, et al: The androgen derivative 5alpha-androstane-3beta, 17 beta-diol inhibits prostate cancer cell migration through activation of the estrogen receptor beta subtype. Cancer Res 65: 5445-5453, 2005.

38. Arpino G, Weiss H, Lee AV, et al: Estrogen receptor-positive, progesterone receptor-negative breast cancer: association with growth factor receptor expression and tamoxifen resistance. J Natl Cancer Inst 97: 1254-1261, 2005.

39. Lindberg MK, Moverare S, Skrtic S, et al: Estrogen receptor (ER)-beta reduces ERalpha-regulated gene transcription, supporting a 'ying yang' relationship between ERalpha and ERbeta in mice. Mol Endocrinol 17: 203-208, 2003.
40. Matthews J, Wihlen B, Tujague M, Wan J, Strom A and Gustafsson JA: Estrogen receptor (ER) beta modulates ERalpha-mediated transcriptional activation by altering the recruitment of c-Fos and c-Jun to estrogen-responsive promoters. Mol Endocrinol 20: 534-543, 2006.

41. Susie S, Hsieh CM: ERbB-2 expression is rate-limiting for epidermal growth factor-mediated stimulation of ovarian cancer cell proliferation. Int J Cancer 86: 644-651, 2000.

42. Kraus MH, Popescu NC, Amsbaugh SC and King CR: Overexpression of the EGF receptor-related proto-oncogene erbB-2 in human mammary tumor cell lines by different molecular mechanisms. EMBO J 6: 605-610, 1987. 